\title{
CROW(TM) Field Demonstration with Bell Lumber and Pole
}

\author{
Topical Report \\ March 1, 1995 - March 31, 1996
}
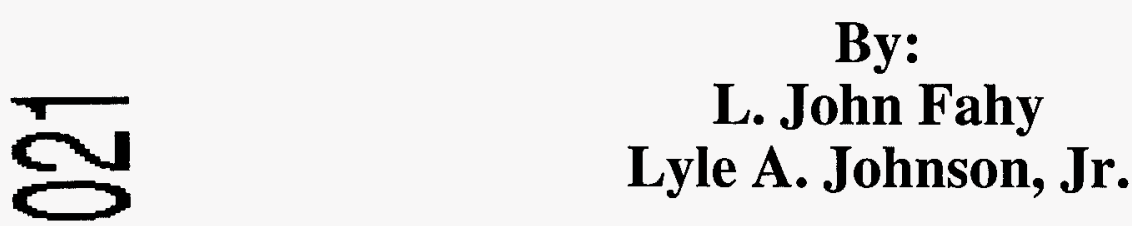

For

U.S. Department of Energy

Office of Fossil Energy

Federal Energy Technology Center

Morgantown Site

P.O. Box 880

Morgantown, West Virginia 26507-0880

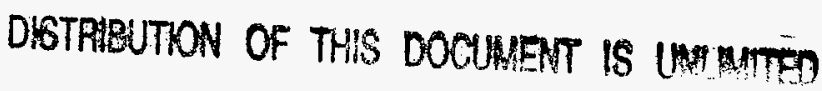<smiles>CC=C(C)Br</smiles>

Western Research Institute

365 North Ninth Street

Laramie, Wyoming 82070 


\section{Disclaimer}

This report was prepared as an account of work sponsored by an agency of the United States Government. Neither the United States Government nor any agency thereof, nor any of their employees, makes any warranty, express or implied, or assumes any legal liability or responsibility for the accuracy, completeness, or usefulness of any information, apparatus, product, or process disclosed, or represents that its use would not infringe privately owned rights. Reference herein to any specific commercial product, process, or service by trade name, trademark, manufacturer, or otherwise does not necessarily constitute or imply its endorsement, recommendation, or favoring by the United States Government or any agency thereof. The views and opinions of authors expressed herein do not necessarily state or reflect those of the United States Government or any agency thereof. 


\section{ACKNOWLEDGMENTS}

This report was prepared with the support of the U.S. Department of Energy (DOE), Morgantown Energy Technology Center, under Cooperative Agreement DE-FC-93MC30127. However, any opinions, findings, conclusions, or recommendations expressed herein are those of the authors and do not necessarily reflect the views of the DOE.

This Report was prepared as an account of work sponsored by an agency of the United States Government. Neither the United States Government nor any agency thereof, nor any of their employees makes any warranty, expressed or implied, or assumes any legal liability or responsibility for the accuracy, completeness, or usefulness of any information, apparatus, product, or process disclosed, or represents that its use would not infringe on privately owned rights. Reference herein to any specific commercial product, process, or service by trade name, trademark, manufacturer, or otherwise does not necessarily constitute or imply its endorsement, recommendation, or favoring by the United States Government or any agency thereof. The views and opinions of the author expressed herein do not necessarily state or reflect those of the United States Government or any agency thereof. 
LIST OF TABLES AND FIGURES $\ldots \ldots \ldots \ldots \ldots \ldots \ldots \ldots \ldots \ldots \ldots \ldots \ldots \ldots$ iv

EXECUTIVE SUMMARY $\ldots \ldots \ldots \ldots \ldots \ldots \ldots \ldots \ldots \ldots \ldots \ldots \ldots \ldots \ldots \ldots$

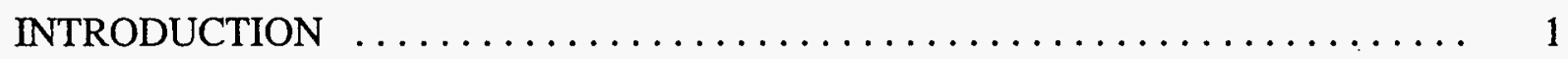

SITE CHARACTERIZATION $\ldots \ldots \ldots \ldots \ldots \ldots \ldots \ldots \ldots \ldots \ldots \ldots \ldots \ldots \ldots$

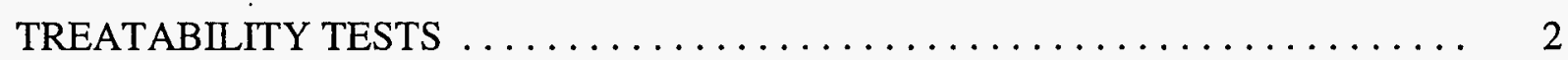

PILOT TEST OBJECTIVES $\ldots \ldots \ldots \ldots \ldots \ldots \ldots \ldots \ldots \ldots \ldots \ldots \ldots \ldots \ldots \ldots \ldots$

PILOT TEST DESCRIPTION $\ldots \ldots \ldots \ldots \ldots \ldots \ldots \ldots \ldots \ldots \ldots \ldots \ldots \ldots \ldots \ldots$

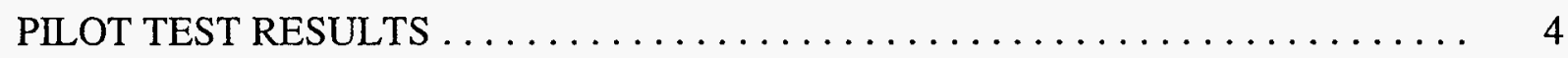

PILOT TEST CONCLUSIONS AND RECOMMENDATIONS $\ldots \ldots \ldots \ldots \ldots \ldots 7$

CROW TEST PROCEDURES AND DESIGN $\ldots \ldots \ldots \ldots \ldots \ldots \ldots \ldots \ldots . \quad 8$

WELL NETWORK DESIGN $\ldots \ldots \ldots \ldots \ldots \ldots \ldots \ldots \ldots \ldots \ldots \ldots \ldots$

SURFACE TREATMENT SYSTEM DESIGN $\ldots \ldots \ldots \ldots \ldots \ldots \ldots \ldots$

CONTROL AND DATA ACQUISITION SYSTEM $\ldots \ldots \ldots \ldots \ldots \ldots \ldots \ldots \ldots, 10$

PROJECT OPERATION $\ldots \ldots \ldots \ldots \ldots \ldots \ldots \ldots \ldots \ldots \ldots \ldots \ldots \ldots \ldots \ldots \ldots \ldots$

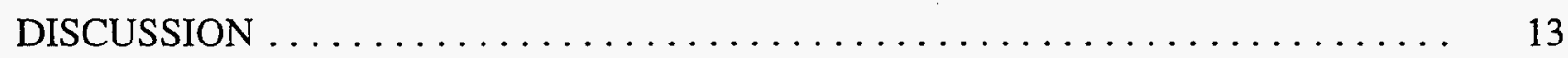

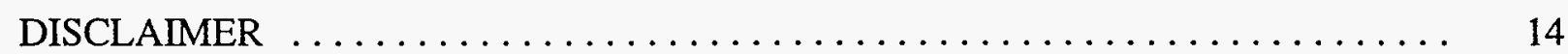

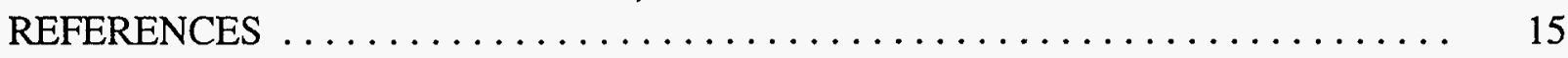




\section{LIST OF TABLES AND FIGURES}

Table

Page

1. Process Simulations for Bell Pole $\ldots \ldots \ldots \ldots \ldots \ldots \ldots \ldots \ldots \ldots \ldots$

2. Pilot Test Operating Conditions and Results $\ldots \ldots \ldots \ldots \ldots \ldots \ldots \ldots$

3. Water Disposal PAH Concentration $\ldots \ldots \ldots \ldots \ldots \ldots \ldots \ldots \ldots \ldots \ldots \ldots \ldots$

4. Bell Pole Crow Test Summary, January 3, 1995 through February 25, 1996 . . . . 11

5. Bell Pole Crow Test Summary, February 26, 1995 through March 28, $1996 \ldots \ldots 12$

6. Process Train Hydrocarbon Sampling, March 13, $1996 \ldots \ldots \ldots \ldots \ldots$

Figure

Page

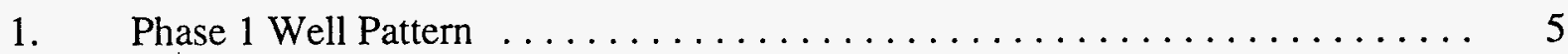

2. Treatment System Conceptual Design $\ldots \ldots \ldots \ldots \ldots \ldots \ldots \ldots \ldots$ 


\section{EXECUTIVE SUMMARY}

The work performed in this study is Task 013 "CROW ${ }^{\mathrm{TM}}$ Field Demonstration with Bell Lumber and Pole" of U.S. Department of Energy cooperative agreement DE-FC21-93MC30127.

Beginning in 1990, efforts were initiated to implement an in situ remediation project for the contaminated aquifer at the Bell Lumber and Pole Company (Bell Pole) Site in New Brighton, Minnesota. The remediation project involves the application of the Contained Recovery of Oily Waste $\left(\mathrm{CROW}^{\mathrm{TM}}\right)$ process, which consists of hot-water injection to displace and recover the nonaqueous phase liquids (NAPL).

While reviewing the site evaluation information, it became apparent that better site characterization would enhance the outcome of the project. Additional coring indicated that the areal extent of the contaminated soils was approximately eight times greater than initially believed. Because of uncertainties, it was determined that a pilot test would assist in the design of the full-scale CROW process demonstration.

Based on the results from the pilot test, the following conclusions were made:

- The pilot test provided sufficient hydraulic information to design the full-scale CROW remediation system. The pumping test portion of the pilot test indicated uniform aquifer properties. The entire thickness of the aquifer reached the target temperature range, and containment of the injected hot water was achieved.

- $\quad$ Pre-test injection and extraction rate predictions were achieved.

- The post-test soil boring data indicated hot-water injection displaced greater than 80 percent of the NAPL near the injection well. The data indicates that a NAPL saturation of approximately 19 percent (pore volume basis) and a 500 fold decrease in pentachlorophenol (PCP) concentration can be achieved with 20 pore volumes of flushing.

- $\quad$ The treatment system used during the pilot test was effective in reducing PCP and polynuclear aromatic hydrocarbon (PAH) compounds to concentrations acceptable for sanitary sewer discharge.

- The microbial assay of the post-test samples found an encouraging increase in microbial population compared to data collected before the pilot test. 
Based on the results from the pilot test, conditions and procedures were developed for implementing a full-scale CROW process demonstration to remediate the remaining contaminated soil at the Bell Pole site.

After reviewing the cost ramifications of implementing the full-scale CROW field demonstration, Bell Pole approached Western Research Institute with a request for a staged, sequential site remediation. Bell Pole's rational for the change in the project scope was prompted by budget restrictions. Bell Pole felt that even though a longer project might be more costly, by extending the length of the project, the yearly cost burden would become more manageable.

After considering several options, WRI recommended implementing a three-phase approach to remediating the contaminated area. Phase 1 will involve a 30-gpm CROW process demonstration to remediate the upgradient, one-third of the contaminated area, which is believed to contain the largest amount of free organic material.

As of late March 1996, the Phase 1 CROW process system is operating. However, hot-water response has not yet been observed at the extraction well. Phase 1 is expected to continue for at least 18 months or until 20 pore volumes have been injected. 


\section{INTRODUCTION}

Beginning in 1990, efforts were initiated to implement an in situ remediation project for the contaminated aquifer at the Bell Lumber and Pole Company (Bell Pole) Site in New Brighton, Minnesota. The remediation project involves the application of the Contained Recovery of Oily Waste $\left(\mathrm{CROW}^{\mathrm{TM}}\right)$ process, which consists of hot-water injection to displace and recover the nonaqueous phase liquids (NAPL) (Johnson and Sudduth 1989).

Wood treating activities began in 1923 and have included the use of creosote and pentachlorophenol (PCP) in a fuel oil carrier. Creosote was used as a wood preservative from 1923 to 1958 . A 5-6\% mixture of PCP in fuel oil was used as a wood preservative from 1952 to the present. Provalene 4-A, a non-sludging fuel-oil-type carrier for PCP, was used from 1952 until it was no longer commercially available in 1968 . From 1968 to the present, a fuel-oil-type carrier P-9 has been used.

While reviewing the site evaluation information, it became apparent that better site characterization would enhance the outcome of the project. Additional coring indicated that the areal extent of the contaminated soils was approximately eight times greater than initially believed. Because of uncertainties, it was determined that a pilot test would assist in the design of the full-scale CROW process demonstration.

\section{SITE CHARACTERIZATION}

Site characterization of the contaminated area at the Bell Pole site has been ongoing for several years by Conestoga-Rovers \& Associates Limited (CRA) and other consultants. The contaminated soil is contained in the New Brighton Formation (Stone 1966). It has been described as a relatively uniform silty fine-medium grain sand, 23 to $47 \mathrm{ft}$ thick beneath the site (CRA 1986). The contaminated soil is underlain by the Twin Cities Formation, which is a silty to sandy clay till. The New Brighton Formation is highly permeable, with hydraulic conductivities in the range of $3.1 \times 10^{-3}$ to $9.5 \times 10^{-3} \mathrm{~cm} / \mathrm{sec}$. Conversely, the underlying Twin Cities Formation has low permeability with a conductivity on the order of $1.0 \times 10^{-7} \mathrm{~cm} / \mathrm{sec}$ (CRA 1986). The low permeable underlying clay till has provided an effective lower boundary to fluid migration and has been responsible for limiting the downward migration of the organic material.

A continuous aquifer lies at a depth of 10 to 20 feet below ground surface (BGS). Groundwater flows radially from a pond, located to the northeast, at a velocity of 0.1 to $0.6 \mathrm{ft} / \mathrm{day}$. 
Across the Bell Pole site the groundwater gradient is $0.004 \mathrm{ft} / \mathrm{ft}$ toward the southwest where the water appears to discharge into a drainage ditch.

In early 1990, twenty-two boreholes were drilled to define the extent of the contamination. Later, in preparation for the two-well pilot test, one new injection well and three monitor wells were also drilled and cored. Based on the evaluation of the coring data, it appears that the contaminated or saturated interval has an elongated teardrop shape that dips toward the northeast (Figure 1). The maximum thickness in the center of the zone is approximately $25 \mathrm{ft}$, while the edge of the contaminated zone is only a foot or two thick.

\section{TREATABILITY TESTS}

While the coring operations were done, two large samples of contaminated soil were collected. These samples were used to conduct laboratory treatability tests. These flushing tests were necessary to appraise the effectiveness of the CROW process at this site and to determine operating conditions.

For each flushing test, approximately $30 \mathrm{lb}$ of the contaminated site material was packed into a 3.75 -in. i.d. by 36 -in. long reactor tube. The reactor tube was then placed vertically within the reactor shell. During the packing of each reactor tube, a composite sample of the packed material was prepared for organic loading determination. Each test was conducted by establishing water flow at the desired flow rate through the bottom of the tube with the flush water produced from the top of the tube.

Two tests were conducted, one each at a nominal $120^{\circ} \mathrm{F}$ and $140^{\circ} \mathrm{F}$. The operating conditions and results for the two flushing tests are listed in Table 1. The reduction in the organic saturation was essentially the same, 0.53 and $0.54 \mathrm{wt} \%$, even with the variance in the weight percent oil for the pretest samples ranges, which was 2.87 to $7.44 \%$.

The initial and post-test samples submitted for PCP analyses show that the decrease in PCP concentration during the flushing tests was greater than the decrease in the total oil phase concentration. 
Test Number

Water Injection

Temperature, ${ }^{\circ} \mathrm{F}$

Flux, $\mathrm{cm}^{3} / \mathrm{min}$

Velocity, $\mathrm{cm} / \mathrm{min}$

Porosity, \%

Initial Oil Saturation of Mobile Oil Zone,

$\%$ Pore Volume

wt \%

Residual Oil Saturation

$\%$ Pore Volume

wt \%

Removal of Oil, wt \%

PCP Concentration, ppm

Initial Material

Flushed Material

\% Reduction
103

140

107

$2.5 \times 10^{-2}$

35.5

42.2

7.44

16.2

2.87

118

$2.8 \times 10^{-2}$

33.6

2.87

10.0

10.0

0.53

93.5

84.3

3200.0

1500.0

2.3

99.9
$\mathrm{BDL}^{\mathrm{a}}$

$99.8^{b}$

a $\mathrm{BDL}=$ Below detection limit

b Value based on the flushed material for test 103

\section{PILOT TEST OBJECTIVES}

An Interim Response Action (IRA) work plan was prepared in 1990 by CRA and Western Research Institute (WRI). The IRA detailed how the CROW process would be implemented at the Bell Pole Site (CRA and WRI 1990). Based on the IRA and after the granting of variances by the Minnesota Pollution Control Agency (MPCA) and the Minnesota Department of Health (MDH), a two-well pilot test of the CROW process was conducted. The test consisted of injecting hot, potable water into the NAPL saturated area of the aquifer, producing groundwater (and NAPL) from an existing extraction well, PW1, and treating the produced water for sanitary sewer discharge.

The objectives of the pilot test were to:

- $\quad$ compare predicted injection and extraction rates with actual field data; 
- demonstrate the ability to heat the aquifer to the $120^{\circ} \mathrm{F}$ to $140^{\circ} \mathrm{F}$ range;

- demonstrate the ability to hydraulically control the injected water to prevent spreading contamination;

- confirm treatment system effectiveness in reducing PCP and polynuclear aromatic hydrocarbons (PAHs) prior to sanitary sewer discharge; and

- predict anticipated operating conditions for full-scale CROW application.

\section{. PILOT TEST DESCRIPTION}

The pilot-test location was selected from the site characterization mapping and the location of the existing extraction well, PW1. One new injection well, IW1, was drilled $50 \mathrm{ft}$ upgradient, to the northeast from well PW1. Both the injection and extraction wells were located in an area that contained high organic accumulations (Figure 1).

The pilot test began on September 24, 1991. The first step of the test involved pumping the extraction well, PW1. Treatment of water began on September 26, day 3 of the test. Hot-water injection started on day 7 at an initial injection temperature of $147^{\circ} \mathrm{F}$. On day 9 , the injection temperature was increased to $203^{\circ} \mathrm{F}$. Injection was terminated on October 31, day 37 of the pilot test. Pumping continued at PW1 until day 41 , when the test ended. Water treatment continued until day 45 , and the treatment system was subsequently dismantled.

\section{PILOT TEST RESULTS}

Flow rates and injection pressures were recorded by the data acquisition system. The pumping rate at PW1 was started at $5 \mathrm{gpm}$ and stepped up to $9 \mathrm{gpm}$ during the seven days prior to injection startup. During the remainder of the test, PW1 averaged $6.5 \mathrm{gpm}$ (Table 2).

The injection rate was relatively constant during the test and averaged $4.5 \mathrm{gpm}$. Injection pressure increased during the test from 6 to $14 \mathrm{psig}$. The hot-water injection temperature remained fairly constant at approximately $200^{\circ} \mathrm{F}$ for the entire 30 days of injection. 


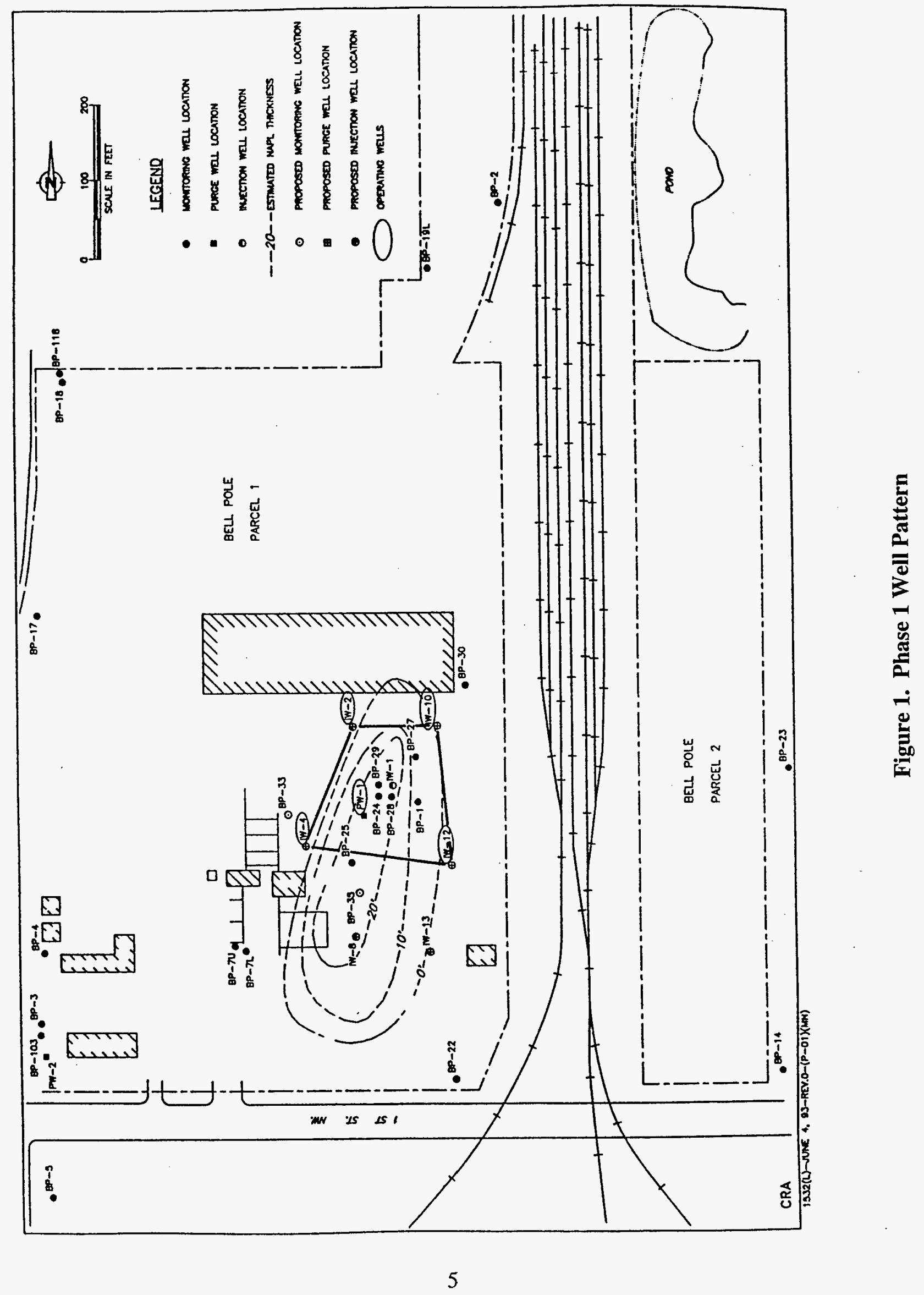




\section{Table 2. Pilot Test Operating Conditions and Results}

Total Hot-Water Injection Time

Average Hot-Water Injection Rate

Steady-State Hot-Water Injection Wellhead Temperature

Total Water Injected

Total Water and NAPL Production Time

Average Fluid Production Rate During Hot-Water Injection Phase

First Pumping Test Production Rate

Second Pumping Test Production Rate

Total Fluids Produced

Total NAPL Production

Areal Extent of Injected Water

Time to NAPL Production Response From Start Of Injection

Time to Breakthrough from Start of Hot-Water Injection

Average Hot-Water Injection Front Velocity, ft/day
30 days

$4.5 \mathrm{gpm}$

$200^{\circ} \mathrm{F}$

193,000 gallons

41 days

$6.5 \mathrm{gpm}$

$5.0 \mathrm{gpm}$

$9.0 \mathrm{gpm}$

390,000 gallons

2000 gallons

$3285 \mathrm{ft}^{2}$

14 days

20 days

$2.5 \mathrm{ft} /$ day

Temperatures were measured at the injection and extraction wellheads and at the monitor well locations. Early temperature data indicated that the hot water might be tending to override and travel predominantly across the top of the aquifer. However, the temperatures in the lower intervals of the aquifer increased until at the end of the 30-day injection period, a temperature profile taken between the injection and extraction wells showed a very uniformly heated front, indicating that the hot water was not traveling across the top of the zone but was heating the entire aquifer.

In all cases, a temperature equal to or greater than the targeted $140^{\circ} \mathrm{F}$ was achieved in the monitor wells located between the injection and extraction wells. Downhole temperature measurements at well PW1 indicated that $150^{\circ} \mathrm{F}$ fluids had reached PW1 prior to the conclusion of the hot-water injection phase. While the hot-water front was growing horizontally from the injection 
well toward PW1, it also expanded vertically. Injection at IW1 occurred into a 15 -ft interval between 20 and $35 \mathrm{ft} \mathrm{BGS}$ and about $5 \mathrm{ft}$ below the top of the water table. However, by the end of the test, the entire thickness of the aquifer had reached the targeted temperature.

After the test was concluded, two boreholes, CT1 and CT2, were drilled and cored. The borehole locations were chosen to represent portions of the aquifer that received two different amounts of hot-water flushing. CT1 represents the aquifer out to approximately $4 \mathrm{ft}$ from IW 1 , and CT2 represents the aquifer out to approximately $10 \mathrm{ft}$ from IW1. The samples taken from the two boreholes were extracted to determine residual NAPL saturations. The residual NAPL saturations determined from the two boreholes were compared to initial conditions obtained from the core taken from the injection well, IW1.

\section{PILOT TEST CONCLUSIONS AND RECOMMENDATIONS}

Based on the results from the pilot test the following conclusions were made:

- The pilot test provided sufficient hydraulic information to design the full-scale CROW remediation system. The pumping test portion of the pilot test indicated uniform aquifer properties. The entire thickness of the aquifer reached the target temperature range and containment of the injected hot water was achieved.

- Pre-test injection and extraction rate predictions were achieved.

- The post-test soil boring data indicated hot-water injection displaced greater than $80 \%$ of the NAPL near the injection well. The data indicates that a NAPL saturation of approximately $19 \%$ (pore volume basis) and a 500-fold decrease in PCP concentration can be achieved with 20 pore volumes of flushing.

- The treatment system used during the pilot test was effective in reducing PCP and PAH compounds to concentrations acceptable for sanitary sewer discharge.

- The microbial assay of the post-test samples found an encouraging increase in microbial population compared to earlier data collected before the pilot test. 


\section{CROW TEST PROCEDURES AND DESIGN}

Based on the results from the pilot test, conditions and procedures were developed for implementing a full-scale CROW process demonstration to remediate the remaining contaminated soil at the Bell Pole site.

After reviewing the cost ramifications of implementing the full-scale CROW field demonstration, Bell Pole approached WRI and the MPCA with a request for a staged, sequential site remediation. Bell Pole's rational for the change in the project scope was prompted by budget restrictions. Bell Pole felt that even though a longer project might be more costly, by extending the length of the project, the yearly cost burden would become more manageable.

After considering several options, WRI recommended implementing a three-phase approach to remediating the contaminated area. Phase 1 will involve a 30-gpm CROW process demonstration to remediate the upgradient, one-third of the contaminated area, which is believed to contain the largest amount of free organic material.

By implementing Phase 1, WRI believes sufficient data will be obtained for large-scale evaluation of the CROW process. Also, this will allow the CROW process evaluation to be completed in the same time frame as originally proposed. The three-phase approach to remediating the site is not expected to cause any adverse effects except for extending the time required to complete the entire project.

\section{WELL NETWORK DESIGN}

During the fourth quarter of 1993, WRI, through a subcontract to CRA, drilled four Phase 1 injection wells and three monitoring wells, plus two Phase 2 injection wells, which will also be used as downgradient monitoring wells during Phase 1.

By using the existing extraction well, PW1 and the new injection wells, an inverted five-spot pattern was installed (Figure 1). PW1 is closer to the downgradient injection wells than to the upgradient injection wells, which is anticipated to enhance the overall capture efficiency of the system. Injection to extraction well spacings are on the order of $100 \mathrm{ft}$, which is about twice the spacing utilized during the pilot test. 


\section{SURFACE TREATMENT SYSTEM DESIGN}

Based on results from the pilot test, plus bench-scale tests conducted by Bell Pole and various vendors, a surface treatment system was designed and installed.

During the pilot test it was observed that a significant amount of oil/water separation was occurring in the 40,000-gal holding tank where all the produced oil and water was being pumped. To capitalize on this occurrence, all produced water and oil will be pumped to a 40,000 gallon tank at a rate of about $30 \mathrm{gpm}$, after sulfuric acid has been added to lower the $\mathrm{pH}$ to approximately 3.5. Oil is both skimmed from the top of the fluid in the tank and pumped off of the bottom of the tank and then routed to an oil holding tank. This is a batch operation and will be done manually once or twice a week.

Water is continuously pumped from the 40,000 gallon tank to an air flotation unit where the oily water is aerated and the majority of the remaining oil and grease, PCP, and total organic carbon (TOC) are removed and recycled back to the 40,000-gal tank.

The treated water leaving the air flotation unit is treated with sodium hydroxide and then pumped to a 10,000-gal equalization tank. From this tank, part of the water, 5 to $10 \mathrm{gpm}$, is pumped to an ozone unit which removes the PCP. The water is then treated with hydrogen peroxide to breakdown the remaining PAH compounds then disposed of to the sewer. The remaining water that is not pumped to the ozone unit, 15 to $20 \mathrm{gpm}$, is recycled through a boiler/heat exchanger system and then reinjected. The conceptual design of the water treatment system is shown in Figure 2.

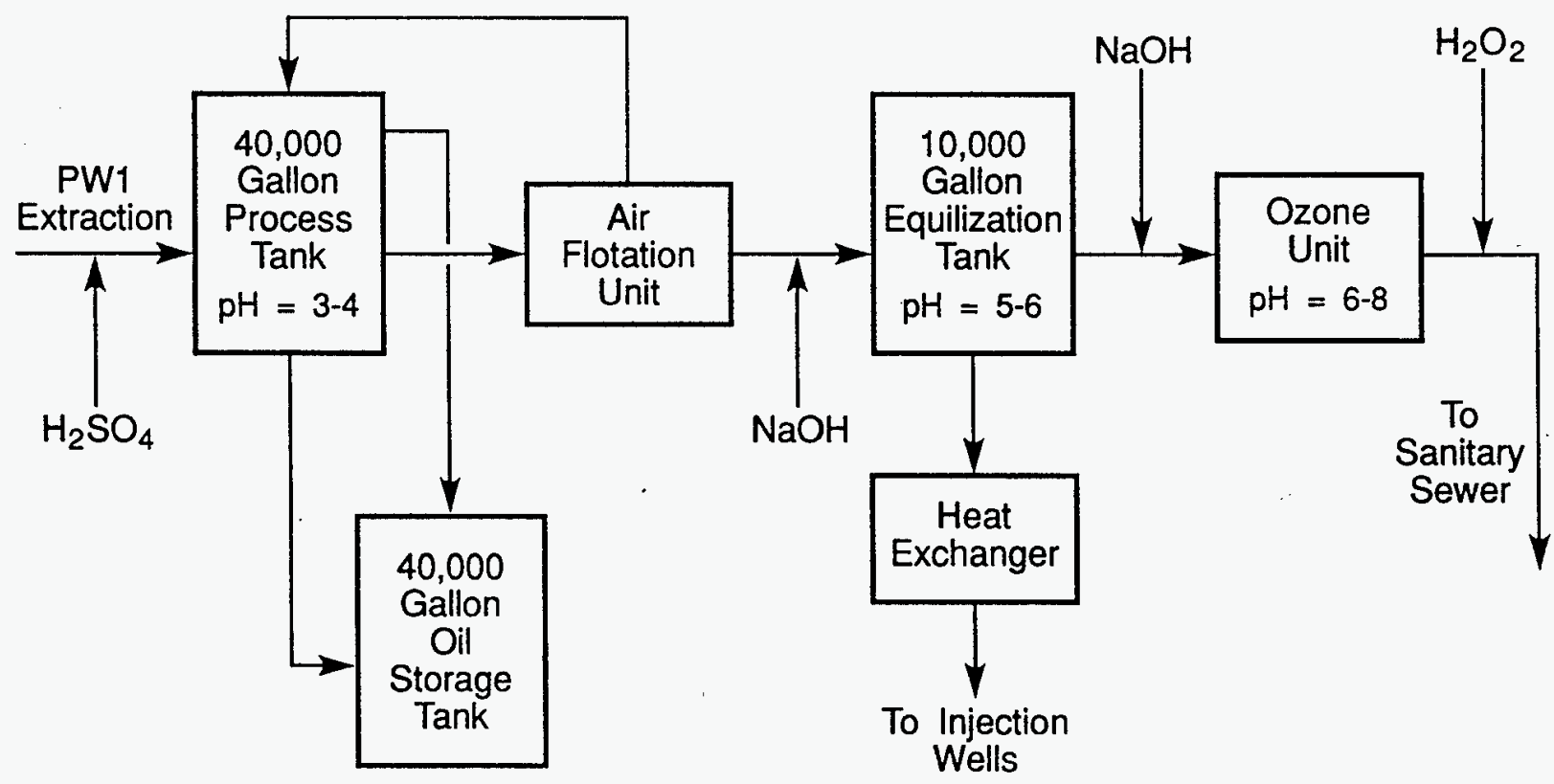

Figure 2. Treatment System Conceptual Design 


\section{CONTROL AND DATA ACQUISITION SYSTEM}

For the Bell Pole Phase 1 CROW demonstration, WRI has developed and installed a control and data acquisition system (CDAS). This system collects all temperature, pressure, flow, and $\mathrm{pH}$ data generated by the process. From this data, the CDAS then makes a decision as to what type of control should be exerted on the process. If required, the CDAS will turn a pump, valve, or alarm on or off as specified by the logic that controls the solid-state relays.

In addition to controlling the physical process, the CDAS also displays the status of the various parameters on the computer monitor through the use of several computer screens. The system also records the status of these parameters to computer files, which are routinely downloaded via the modem system for analysis and archiving.

From the start, the CDAS system operated basically as designed. However, the computer had hung up occasionally. In October 1995, an upgrade of the control system and Windows 95.0 were installed. These upgrades have eliminated the previous problems and the system has been operating trouble free.

\section{PROJECT OPERATION}

By early 1995 all of the equipment, except for the hydrogen peroxide system, had been installed. Water extraction began March 1995 and the system was operated intermittently through April 1995. On May 16, 1995, continuous operation of the CROW system began. Continuous hotwater injection was terminated on June 29 , and continuous extraction and disposal of excess water to the sewer was terminated July 12,1995. The system was shut down primarily as a result of failure to meet discharge criteria. A secondary reason for termination was mechanical failure of the water heat exchanger, which was subsequently replaced.

The ozone unit was originally designed for removal of PCP. However, high concentrations of total PAHs, particularly naphthalene and phenanthrene, in excess of the discharge criteria were occurring (Table 3). After several attempts to reduce the PAH concentration in the discharge water, the hydrogen peroxide injection system was installed downstream of the ozone unit. Hydrogen peroxide injection brought the PAH concentrations down to acceptable discharge limits (Table 3).

Upon demonstrating that the discharge criteria could routinely be met, the water contained in the water treatment system was treated and disposed of, and extraction from PW1 was restarted (Table 4). Continuous groundwater extraction was established February 26, 1996, and continuous 
Table 3. Water Disposal PAH Concentration

\begin{tabular}{lccc}
\hline PAH Compound & $\begin{array}{c}\text { Before Hydrogen } \\
\text { Peroxide Injection } \\
\text { (ug/L) }\end{array}$ & $\begin{array}{c}\text { After Hydrogen } \\
\text { Peroxide Injection } \\
\text { (ug/L) }\end{array}$ & $\begin{array}{c}\text { Discharge } \\
\text { Limits } \\
(\mathrm{ug} / \mathrm{L})\end{array}$ \\
\hline Naphthalene & $\mathbf{3 9 0 0}$ & 630 & 3000 \\
Acenaphthene & 530 & 40 & 3000 \\
Fluorene & $\mathrm{BDL}$ & 340 & 3000 \\
Pentachlorophenol & $\mathrm{BDL}$ & 280 & 3000 \\
Phenanthrene & $\mathbf{5 2 0 0}$ & 780 & 3000 \\
Anthracene & 340 & 37 & 3000 \\
Fluoranthene & 1100 & 360 & 3000 \\
Pyrene 1400 & 370 & 3000 & 3000 \\
Benzo-a-anthracene & 260 & 57 & 3000 \\
Chrysene & 340 & 110 & 3000 \\
Benzo-b-fluoranthene & $\mathrm{BDL}$ & 23 & 3000 \\
Benzo-k-fluoranthene & $\mathrm{BDL}$ & 60 & 3000 \\
Benzo-a-pyrene & $\mathrm{BDL}$ & 14 & 3000 \\
2-Methylnapthalene & 1400 & 290 & 10000 \\
Total PAH Concentration & $\mathbf{1 4 4 7 0}$ & 3391 & \\
\hline
\end{tabular}

Below Detection Limits

Table 4. Bell Pole Crow Test Summary, January 3, 1995 through February 25, 1996

\begin{tabular}{lc}
\hline Total Water Injected, gal & 222,811 \\
Total Water Extracted, gal & 642,138 \\
Total Water Disposed, gal & 543,315 \\
$\quad$ (includes water from Pre-existing pump and treat wells) \\
Total Water Inventory in Tanks, gal & 25,890 \\
\hline
\end{tabular}


hot-water injection began a week later on March 4, 1996 (Table 5). To date, a temperature response has not been observed at the extraction well. However, oil production is continuing.

On March 12, 1996, the entire water treatment system was analyzed for oil and grease concentration and partially analyzed for PCP and total PAH concentration (Table 6). The extraction well, PW1, oil and grease concentration was uncharacteristically low, suggesting groundwater pumping prior to hot-water response has lowered the oil concentration in the immediate area. PW1 oil and grease concentrations had typically been in the $1000-3000 \mathrm{mg} / \mathrm{L}$ range when sampled earlier.

Table 5. Bell Pole Crow Test Summary, February 26, 1996 through March 28, 1996

Continuous Extraction Time, days $\quad 32$

Hot-Water Injection Time, days $\quad 25$

Average Heater Temperature, ${ }^{\circ} \mathrm{F} \quad 163$

Average Injection Manifold Temperature, ${ }^{\circ} \mathrm{F} \quad 161$

IW4 Injection Line Temperature, ${ }^{\circ} \mathrm{F} \quad 155$

PW1 Average Aquifer Temperature, ${ }^{\circ} \mathrm{F} \quad 56$

Injection Well Aquifer Temperature Range, ${ }^{\circ} \mathrm{F} \quad 152-158$

Total Hot-Water Injected, gallons $\quad 401,904$

$\begin{array}{lr}\text { Total Water Extracted, gallons } & 662,688\end{array}$

$\begin{array}{lr}\text { Total Water Disposed, gallons } & 315,072\end{array}$

(Includes PW2 and PW3)

$\begin{array}{lr}\text { Pattern Pore Volume, gal } & 800,000\end{array}$

$\begin{array}{lr}125 \% \text { Pattern Pore Volume, gal } & 1,000,000\end{array}$

Total Water Injected, pore vol $\quad 0.4$

$\begin{array}{ll}\text { Total Water Extracted, pore vol } & 0.7\end{array}$

$(1,000,000 \mathrm{gal} / \mathrm{PV})$

Average Pattern Injection Rate, gpm $\quad 11.2$

Average Pattern Extraction Rate, gpm $\quad 14.9$

Average Water Disposal Rate, gipm $\quad \cdots \quad 6.8$

Cumulative Product Recovery, gal ·

Individual Injection Well Flow Rates, gpm

IW2 3.1

IW4 $\quad 2.0$

IW10 4.1

IW12 3.1 
PW1 Influent

Oil and Grease Concentration, $\mathrm{mg} / \mathrm{L}$

After Air Flotation Unit

Oil and Grease Concentration, $\mathrm{mg} / \mathrm{L}$

Injection Water

Oil and Grease Concentration, $\mathrm{mg} / \mathrm{L}$

96

PCP Concentration, $\mathrm{mg} / \mathrm{L}$

Discharge Water

PCP Concentration, $\mathrm{mg} / \mathrm{L}$

$<1$

Total PAH Concentration, $\mathrm{mg} / \mathrm{L}$

$<4$

The oil and grease concentration after the air flotation unit has been reduced significantly compared to earlier results, and this is attributed to operating at a lower $\mathrm{pH}$. Better operation of the air flotation unit is evident by the fact that the oil and grease concentration downstream of the air flotation unit was lower than the oil and grease concentration farther downstream in the injection water.

\section{DISCUSSION}

The Bell Pole Phase 1 CROW demonstration is operating satisfactorily, although at less than the design conditions. Efforts are underway to increase the injection temperature to the $195-200^{\circ} \mathrm{F}$ range which will improve the aquifer temperature response. Also, the water injection and extraction rates will be increased to approximately 20 and $30 \mathrm{gpm}$, respectively. Oil continues to be produced, and the production rate is expected to increase as the aquifer temperature increases.

Phase 1 is expected to continue for at least 18 months or until 20 pore volumes have been injected. As the system has been operating continuously for only a month, it is too early to make any additional performance predictions. 


\section{DISCLAIMER}

Mention of specific brand names or models of equipment is for information only and does not imply endorsement of any particular brand. 


\section{REFERENCES}

Conestoga-Rovers and Associates Limited, 1986, Remedial Investigation Phase One Report Bell Lumber and Pole Company Site New Brighton, Minnesota, Unpublished Report, 58 p.

Conestoga-Rovers and Associates Limited and Western Research Institute, 1990, Interim Response Action Work Plan Bell Lumber and Pole Company Site, New Brighton, MN, Unpublished Report, $40 \mathrm{p}$.

Johnson, L.A., and B.C. Sudduth, 1989, Contained Recovery of Oily Waste, United States Patent No. 4,848,460, Western Research Institute, Laramie, WY, 12 p.

Stone, J.E., 1966, Surficial Geology of the New Brighton Quadrangle, Minnesota, University of Minnesota Press, Minneapolis, MN, 39 p. 


\section{M97005486}

||||||||||||||||||||||||||||||||||||||||||||||||

Report Number (14)DOE/MC/ $30 / 27 \cdots .5789$

Jubl. Date (11) $\frac{1997 / 0}{\mathrm{DOE} / F E, X F}$
sponsor Code (18)
IC Category (19) 